\title{
Islamic Corporate Governance, Islamicityfinancial Performance Index And Fraudat Islamic Bank
}

\author{
Rika Lidyah \\ Faculty of Islamic Economics and Business \\ State Islamic University Raden Fatah Palembang \\ rikalidyah_uin@radenfatah.ac.id
}

\begin{abstract}
This research empirically tested the factors of fraud occurrence in sharia banks based on fraud triangle theory, which is motivation, opportunity and rationalization must be fulfilled for the occurrence of fraud. This research develops indicators as a proxy of motivation, opportunity and rationalization. Factors tested in this research is the Islamic Corporate Governance to fraud with the Islamicity Financial Performance Index as a mediator in sharia banks 2012-2016.This research using quantitative method with secondary data. Data are obtained from annual reports published by Islamic banks. The test is done by path analysis and processed using SPSS. The result of research shows that Islamic Corporate Governance has no effect to Islamicity Performance Index, Islamic Income Ratio, Profit Sharing Ratio and Islamic Investment Ratio (Islamicity Financial Performance Index) influence to Fraud, Islamic Corporate Governance has no effect to Fraud, and Islamic Income Ratio, Profit Sharing Ratio and Islamic Investment Ratio (Islamicity Financial Performance Index) does not mediate the influence of Islamic Corporate Governance to Fraud on Islamic Bank or it can be said that there is no mediation. This research shows that factors based on fraud triangle are effective for use in explaining fraud.
\end{abstract}

Keywords: Islamic Corporate Governance, Islamicity Financial Performance Index,Fraud

\section{BACKGROUND}

Islamic bank is a representation of the needs of the Muslim community in the financial sector in accordance with the concept of maslahat. Islamic Bank is a bank which in its activities, both in fund raising and in the framework of distribution of its grant and assignment based on sharia principles (Rodoni and Hamid, 2007).

Constitution of the Republic of Indonesia No. 21 of 2008regardingIslamic banking regulates all matters concerning Islamic Banks and Islamic Business Units, including institutional, business activities, and ways and processes in conducting its business activities. While the definition of Islamic banks is a bank that runs its business activities based on Sharia principles. According to its type, Islamic banks consist of Sharia Commercial Bank (BUS), Sharia Business Unit (UUS) and Sharia Rural Bank (BPRS).

The first Islamic bank appeared in the village of MitGhamr one of the areas in Egypt. Spearheaded by an economist named Dr. Ahmad El Najjar who formed a financial institution which in its operations does not charge interest to the borrower or pay interest to the savers, besides this bank also make direct investment or in the form of partnership with other parties and further divide the profits with the savers, financial institutions Is named MitGhamr Saving Bank or commonly called MitGhamr Bank (Yaya, 2014) 
MitGhamr Bank's success inspired many parties including the Organization of Islamic Conference (OIC) which comprised of governments from various Muslim countries to establish the Islamic Development Bank (IDB) in 1973 and started operations in 1975 with headquarters in Jeddah (Yaya, 2014). IDB operations in Jeddah triggered the establishment of Islamic banks around the world including in Europe and Asia (Falikhatun, 2012). In Southeast Asia, the development of Islamic banking occurred in 1983 with the establishment of Bank Islam in Malaysia followed by the establishment of the first Islamic bank in Indonesia, namely Bank Muamalat Indonesia in 1992 (Yaya, 2014).

The establishment of Bank Muamalat is a pioneer in the development of Islamic banking in Indonesia with other emerging Islamic banks (Sukardi, 2012). The development of Islamic banking in Indonesia is increasing rapidly after the legalization of UU RI No. 21 of 2008 on Islamic Banking (Falikhatun, 2012). These developments can be seen from the total of banks and the total of offices of both Sharia (BUS), Sharia (Islamic) Business Unit, and Sharia Rural Bank (BPRS).

The decreasing number of Islamic banks has implications on the increasing number of challenges facing Islamic banks, where the biggest challenge is to maintain their image and reputation in order to maintain their trust and loyalty to Islamic banks (Falikhatun, 2012). As is known bank is a bank that runs all business activities based on sharia principles derived from Al-Qur'an, Hadith and Ijmak the scholars applied both within the environment and outside the company (Maradita, 2012).

The question arises whether with the element of sharia guarantees an institution free from fraud? The reality is not, as evidenced by the existence of cases of fraud that occurred in Islamic financial institutions. As is the case with Bank SyariahMandiri involving the internal bank, which is fictitious credit distribution in BSM Bogor branch of 102 billion rupiah to 197 fictitious customers. As a result of the loan disbursement BSM potentially suffered a loss of 59 billion rupiah. On the case, the Police Criminal Investigation Unit has established four suspects in which three of them are employees of BSM (Prabowo, 2013).

Not only in Indonesia, some cases of fraud in Islamic banks have also occurred in other countries, such as what happened to the Dubai Islamic Bank, which lost about US \$ 300 billion due to unfair financial reports and the Islamic Bank of South Africa which Bankrupt in 1997 with debts between R50 to R70 million caused by bad management and improper accounting and management systems (Rini, 2014). From these cases proves that there is no guarantee that sharia institutions, especially sharia-based banks, are free from fraud.

Fraud in an organization can be done by various levels ranging from lower levels, management to owners (Anugerah, 2014). For that as an entity that has a special character, Islamic financial business has a high risk in its management, so it takes the prudential principle of the perpetrators in the aspect of Sharia compliance as an effort to prevent the possibility of risk of fraud (Sula, 2014). In order to comply with the provision of compliance information for Islamic banking on the principles of sharia, Hameed et al. (2004) recommended the Islamic Desclosure Index (IDI) developed based on three components of Islamic disclosure indicators, namely sharia compliance, corporate governance and social / environment disclosure (Asrori, 2011).

Bank Indonesia (2009) stated that to encourage the practice and performance of Islamic banking that is healthy and financially resilient and constantly refers to the 
principles of sharia and protect the interests of stakeholders, the Islamic banks are expected to implement the principles of Good Corporate Governance (GCG) that is transparency, accountability, Responsibility, professional, fairness and must comply with sharia principles.

According to Algoud\& Lewis (2001), the issue of governance in Islamic banking is very different from conventional banks. Islamic banks have an obligation to comply with the principles of sharia in carrying out its business activities (Sukardi, 2013). Bank Indonesia (2009) states that the implementation of Sharia principles can be built with the implementation of Good Governance of Sharia Business (GGBS) as set forth in the General Guidelines published by the National Committee on Governance Policy (KNKG) in 2011. Bank Indonesia (2009) can only be implemented with islamic principles but also with the provisions of sharia. Bank Indonesia hereby publishes the implementation of GCG of Sharia Commercial Bank and Sharia Business Unit in Bank Indonesia Regulation No 11/33 / PBI / 2009 and Bank Indonesia Circular Letter No. 12/13 / DPbs dated April 30, 2010.

Company performance can be seen from the financial statements made each period. Analysis of financial statements of Islamic banks in this case is done by using Islamicity financial performance index. This index provides benefits to assist stakeholders such as depositors, shareholders, religious bodies, government and others to evaluate the performance of Islamic financial institutions (Hameed et al., 2004).

Measuring the performance of Islamic banks by Sebtianita (2015) can use the Islamic financial performance index which has several indicators, such as profit sharing ratio, zakat performance ratio, equitable distribution ratio, directors-employees welfare ratio, Islamic investment vs non-Islamic investment, Islamic income vs. non-Islamic income, AAIOIFI index (Accounting and Auditing Organization for Islamic Financial Institutions).

Various studies related to the implementation of good corporate governance which affect the financial performance of Islamic banks show diversity. The results of research conducted by Novitasary (2014) in banking operating in Indonesia found that the value of GCG composite did not affect the performance with the direction of negative relationship. As for Hisamuddin\&Tirta K (2012) studies, good corporate governance is measured by indicators of the size of the board of directors, the size of the board of commissioners, the proportion of independent board of commissioners, the size of the sharia supervisory board, the institutional ownership and the size of the audit committee. While for financial performance measured with indicator Return on Assets (ROA) and Return on Equity (ROE). From the results of the study found that there is a positive influence between good corporate governance on the financial performance of sharia commercial banks.

Based on the above description, the researcher is interested to conduct research related to Islamic Corporate Governance, Islamicity Financial Performance Index and Fraud at Islamic Bankbecause firstly, Islamic Corporate Governance, Islamic Financial Financial Performance Index is a very important element in Islamic Banking, weakness of Islamic Corporate Governance as well as low Islamicity Financial Performance Index can affect performance and provide opportunities for the occurrence of Fraud at Bank Syariah. Secondly, the researcher wants to know whether Islamicity Financial Performance Index and Islamic Corporate Governance applied in Syariah Banking in Indonesia have an effect on Fraud on Sharia Bank. Thirdly, until the completion stage of this research, researchers have not found any research that specifically examines the influence of Islamicity 
Financial Performance Index and Islamic Corporate Governance against fraud in Bank Syariah. Fourth, researchers have not found a study that specifically examines the Islamicity Financial Performance Index as a mediation variable.

\section{THEORETICAL REVIEW}

Agency Theory. The agency theory is the basic thing used to understand the relationship between principle and agent. In this case agency relationships are contracts between one or more persons who employ others to provide a service and then delegate decision-making authority to the agent (Jensen and Meckling, 1976).

Based on this theory, there is a separation between the owner (principal) and the manager of the company (agent), causing agency problem. Furthermore, the separation of owners and managers also raises information asymmetry is a situation where the agent has access to information that is not owned by the principle. Information asymmetry occurs when agents are more familiar with internal information and future prospects, than knowledge of information known to principals and other stakeholders (Anugerah, 2014). Based on the assumptions of human nature, every human being has a tendency to act by giving priority to his personal interests (Jensen and Meckling, 1976).

Differences of interest lead to agents abusing its obligations in the delivery of information to the principal by giving or withholding the requested information favorable to the principal if the agent (Jensen and Meckling, 1976). To overcome this, it is necessary to apply Good Corporate Governance and its principles and mechanisms to ensure that rights and relationships among all stakeholders are assured (Anugerah, 2014).

Good Corporate Governance Islamic Bank. Good Corporate Governance (Forum for Corporate Governance in Indonesia, 2001) is a set of rules governing relationships between shareholders, managers of companies, creditor parties, governments, employees and other internal and external interest holders relating to the rights and their obligation or in other words a system that regulates and controls the company.

In Islamic Banking, governance issues are different from governance in a conventional bank because Islamic banking has an obligation to obey a different set of rules, namely Islamic law (Shari'a) and generally follow the expectations of Muslims by providing partnership capital based on the arrangements of Profit and Loss Sharing (PLS) Or other means of financing justified by sharia (Lewis et al, 2004 in Sudaryati and Eskadewi, 2012).

Bank Indonesia (2009) explains that in encouraging Islamic banking practices that are strong and healthy financially and consistently referring to Sharia principles, Islamic banks are expected to implement GCG principles in the form of Transparency, Accountability, Responsibility, Freedom and Fairness and also Adherence to Sharia provisions (Jumansyah and Syafei, 2013).

Businesses that are run with good governance will tend to be more sustainable in a sustainable way. According to the National Committee on Governance Policy (KNKG) (2011), the ability to maintain business sustainability is essential to benefit all stakeholders. It is certainly not fully applicable to Sharia business institutions, especially Islamic banking, because in Sharia business institutions required a Good Governance Sharia Business (GGBS) that can protect the interests of all stakeholders (stakeholders). 
Islamic Bank Performance (Islamicity Financial Performance Index). Performance in the dictionary of accounting terms is the quantification of effectiveness in the operation of a business over a certain period. The performance of banks in general is a picture of the achievements achieved by banks in their operations. The bank's financial performance is a description of the bank's financial condition for a certain period, covering both the fund raising aspect and its fund distribution. Performance shows something related to the strengths and weaknesses of a company. Such strengths are understood in order to be exploited and weakness must be known in order to make remedial measures.

Performance measurement is a method of measuring company achievement based on predetermined targets. This is part of the control measures that can assist the company in improving future performance during identifying the shortage of operations over operations within a period. To have a good and proper performance measurement system is very important, especially in today's borderless world where companies must remain competitive and financially strong (Hameed et al., 2004).

Evaluating the performance of Islamic financial institutions is as important as measuring individual achievement. It is clear that the roles and responsibilities of Islamic financial institutions are not only limited to the financial needs of various parties, but the most important is how they conduct their business and the actions used to ensure that all activities are in accordance with sharia.

One way to measure the performance of sharia financial institutions is through the indexes proposed by Hameed et al. (2004) ieIslamicity Index, so the performance of Islamic financial institutions can be really measured. This index consists of seven ratios which is a reflection of the performance of sharia banks. Of the seven ratios of Islamicity Index, not all of them can be used in the measurement of financial performance due to the lack. In this study only Profit Sharing Ratio (PSR), Islamic Investment, and Islamic Income are used.

Fraud. According to the Association of Certified Fraud Examiners Fraud as an act of fraud or mistake made by a person or body that knows that such mistakes may result in some unfavorable benefits to an individual or entity or other party.

According to the AICPA, ACFE and IIA in the Managing the Business of Fraud define fraud as an illegal act or undertake undesirable deliberate activity with the intent to outbid others in which the victim suffers a loss and the fraudor makes a profit.

According to Bank Indonesia, Fraud is a deliberate act or omission which is intentionally committed to deceive, deceive or manipulate the Bank, customers, or other parties, taking place within the Bank and / or using the Bank's means to cause Bank, customers or other parties Suffer loss and / or perpetrator Fraud obtains financial gain either directly or indirectly.

According to Arthur W. Holmes and David C. Burns the act of fraud is a misstatement of a material fact that is known to be incorrect or presented by ignoring the principles of truth, with the intention of deceiving others and causing the other party to be disadvantaged ( Institute for Fraud Auditing Development, 2008). The definition of fraud in this regard includes (but is not limited to manipulation, misuse of office, tax evasion, theft of assets, and other bad acts committed by anyone who may cause harm to the organization / corporation. 
Fraud Triangle Theory. The traditional study of fraud was first done by DonaladCrasey in the 1950s which raises the question of why fraud can occur. The results of that study led to the triggering factors of cheating now known as the "Fraud Triangle". Fraud triangle explains the three factors present in every fraud situation:

1. Pressure, that is the incentives / pressure / needs to do fraudThe pressures can cover almost anything including lifestyle, economic demands, and others including financial and non-financial.

2. Opportunity, the situation that opens the opportunity to allow a cheating to happen.

3. Rationalization, ie an attitude, a character, or a set of ethical values that allow certain parties to commit acts of cheating, or those in a pressing environment that makes them rationalize the act of fraud.

All three of the above are illustrated in the following figure:

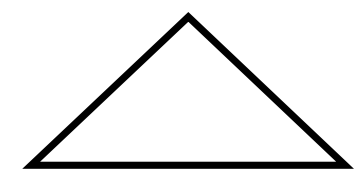

\section{Rationalization Opportunity}

Figure 1. Fraud Triangle Incentive/Pressure

Source: Fraud Triangle Theory (Crassey, 1953)

Internal Fraud according to Bank Indonesia (2007), is a fraud committed by the management, permanent and non-permanent employees (honorary and outsourced) related to the work process and bank operations that significantly affect the Bank's financial condition. What is meant by significantly affecting the Bank's financial condition is if the deviation impact is more than Rp100,000,000.00 (one hundred million rupiah).

The framework of thought in this study can be described in Figure 2

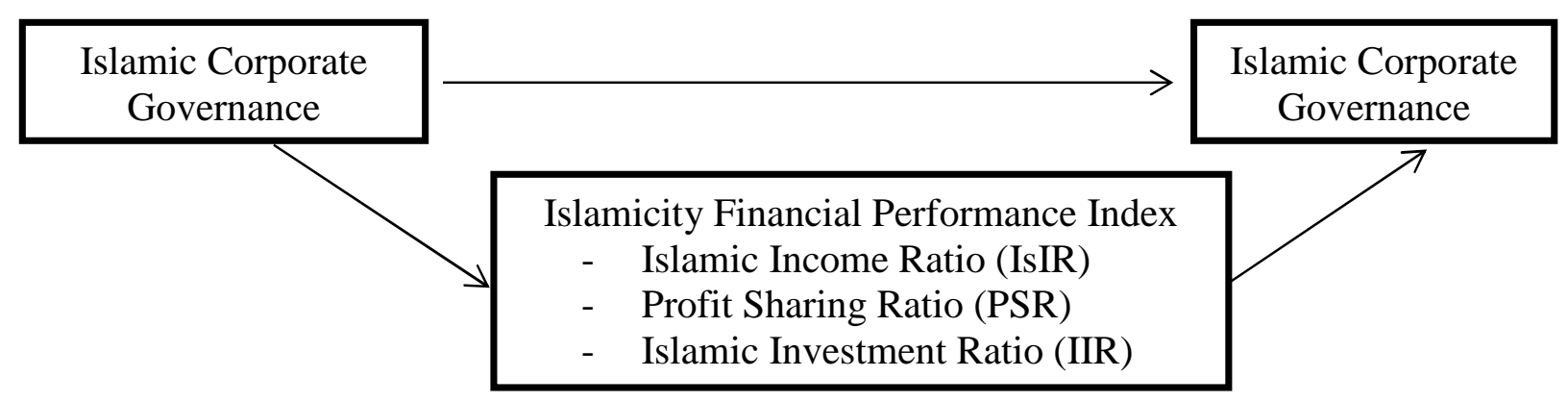

Figure 2. Framework

The influence of Islamic Corporate Governance on the Islamicity Performance Index. Bank Indonesia (2009) explains that in encouraging Islamic banking practices that are strong and healthy financially and consistently referring to Sharia principles, Islamic banks are expected to implement GCG principles in the form of Transparency, ISSN 2460-0784 National Seminar and The 2nd Call For Accountability, Responsibility, Freedom and Fairness as well as compliance with Sharia provisions (Jumansyah and 
Syafei, 2013). Bank Indonesia (2009) recognizes that the implementation of GCG for Sharia banks can not only be based on GCG principles but must also be guided by Sharia provisions. To that end, Bank Indonesia (2009) issued Bank Indonesia Regulation (PBI) no. 11/33 / PBI / 2009 dated December 7, 2009 regarding Good Corporate Governance for Sharia Bank (GGBS) and SE BI No.12 / 13 / DPbS dated April 30, 2010 regarding GCG Implementation for Sharia Commercial Bank and Sharia Business Unit.

Good Governance Business Sharia (GGBS) is one of the important elements in maintaining the sustainability of business growth. Businesses that are run with good governance will tend to be more sustainable in a sustainable way. According to the National Committee on Governance Policy (KNKG) (2011), the ability to maintain business sustainability is essential to benefit all stakeholders. Implementation of GGBS by Islamic banks in Indonesia can be illustrated through the achievement of the GGBS Implementation Index.

Many opinions state that the implementation of Good Governance Business Sharia (GGBS) in Islamic bank is a way to improve economic dynamics and therefore improve the economic performance of sharia banks as a whole. The idea of implementing GGBS is the starting point for the change of work culture in Islamic bank. With the implementation of Good Governance Business Sharia (GGBS), it is expected that Islamic banks can run in accordance with the principles of healthy practices in all fields.

Implementation of Good Governance Business Sharia (GGBS) in accordance with applicable regulations will make investors give a positive response to the company's performance and market value of the company. Measuring the performance of institutions that operate based on the principles of sharia, certainly different from other companies, especially on the orientation. As an institution that moves based on Sharia principles, Islamic banks certainly have different characteristics from other companies in the orientation of their performance. Hameed et al. (2004) presents an alternative performance measurement for Islamic Bank, through an index called Islamicity Indices, which consists of the Islamicity Disclosure Index and the Islamicity Performance Index. This index aims to help the stakeholders in assessing the performance of Islamic banks. This index is then used in assessing the performance of Islamic financial institutions.

In achieving good financial performance, the management of Islamic banks should refer to governance standards and guidelines in accordance with Sharia principles. Bank Indonesia (2009) encourages the management of Islamic banks in Indonesia to refer to the principles of Good Governance Business Sharia (GGBS). Bank Indonesia (2009) expects that the management of Islamic banks based on GGBS principles will encourage the establishment of a financially sound Islamic bank but also a Islamic bank that adheres to Sharia principles in all its operational lines.

H1 : Islamic Corporate Governance has a positive effect on Islamic Income Ratio (Isir) in Islamic Bank.

H2 : Islamic Corporate Governance positively affects Profit Sharing Ratio (PSR) in Islamic Bank.

H3 : Islamic Corporate Governance positively affects Islamic Investment Ratio (IIR) in Islamic Bank.

Effect of Islamicity Financial Performance Index on Fraud. One of the important pillars in Islamic bank development is sharia compliance (Islamicity Financial Performance Index). This pillar is the main differentiator between Islamic banks and 
conventional banks. To ensure the application of sharia principles in banking institutions, sharia supervision is required by the Sharia Supervisory Board (DPS) (El Junusi, 2012).

Compliance and suitability of the Bank on sharia principles are often questioned by customers (El Junusi, 2012). In the main points of the research, Bank Indonesia states that customers who use the services of Islamic Bank have a tendency to stop being customers, among others, because of doubt about the consistency of the application of sharia principles (El Junusi, 2012). Implicitly it shows that the practice of Islamic banking so far less attention to the principles of sharia which became one of the things that can affect the reputation and trust of the community in Islamic banks, it will also affect the loyalty of the community using the services of Islamic banks (El Junusi, 2012 ).

The study of Syafi'iet. Al (2004) in Asrori (2011) found empirical evidence of Sharia compliance practice in financial reporting of sharia banks in Indonesia is still low. Allegedly trust accountant and manager of sharia bank against the use of sharia compliance disclosure practice as accountability of Islamic bank compliance to sharia principle still low.

Low compliance with sharia principles provides an opportunity for fraud to occur in Islamic Banks. Therefore, the guarantee of compliance with sharia principles (syariah compliance) from all customer fund management activities by Islamic bank is very important in Islamic bank business activities (El Junusi, 2012).Based on the results of Chapra\& Ahmad's research (2002) in El Junusi (2012), where 288 customers (62\%) of 463 customers were involved in the GCG survey (derived from 14 sharia banks in Bahrain, Bangladesh And Sudan) said they would transfer their funds to other Islamic banks if it is suspected that there were "fraud" in Islamic bank operations. This shows that the aspect of adherence to sharia principles is very significant affect the behavior of customers in choosing Islamic banks.

Not many studies have examined the effect of sharia compliance on fraud. Previous research on sharia compliance is dominated by testing between sharia compliance and the performance or health of the Sharia Bank. As the study conducted by Hameed et al. (2004) on the disclosure and measurement of the performance of sharia banks, the study compares the Bahrain Islamic Bank with Bank Islam Malaysia Berhad by using the Islamic Disclosure Index (IDI). The Shameah's valuation index index, which Hameed discloses, consists of three factors: Sharia compliance indicators, corporate governance indicators and social indicators. The results show that the performance of Bahrain Islamic Bank (BIB) is better than the Islamic Bank MalaysiaBerhad (BIMB).

Furthermore, the research conducted by Asrori (2011) on the attitudes and interests of accountants and managers of sharia banks to the practice of Shariah compliance, shows the result that accountants and managers of sharia banks are positive towards sharia compliance disclosure practices. Then the research conducted by Falikhatun (2012) which examines the influence of Shariah compliance on the health of finansila sharia bank, which results show that the compliance of sharia has a significant effect on the financial health of Islamic banks.

In this study examined the effect of sharia compliance (Islamicity Financial Performance Index) using indicators included in the Islamicity Disclosure Index (IDI) developed by Hameed et al. (2004), the indicator is, Islamic Income Ratio (IsIR), Profit Sharing Ratio (PSR), Islamic Investment Ratio (IIR). Based on previous theories and research on sharia compliance and its effect on fraud as described above, hence can be compiled research hypothesis as follows: 
H4 : Islamic Income Ratio (Isir) has a negative effect on fraud in Islamic Bank. H5 : Profit Sharing Ratio (PSR) has a negative effect on fraud in Islamic Bank.

H6 : Islamic Investment Ratio (IIR) has a negative effect on fraud on IslamicBank.

The Influence of Islamic Corporate Governance on Fraud. Implementation of GCG principles becomes a necessity for an institution, including the institution of an Islamic bank. This is more directed to the public accountability in relation to the bank's operational activities which are expected to fully comply with the provisions set forth in the positive law. In addition, it is also related to the compliance of sharia banks against the principles of sharia as outlined in the Qur'an, Hadith, and Ijmak of the scholars (Maradita, 2014).

The operation of this Islamic bank is inseparable with the demands of good corporate governance and based on the principles of sharia, called Islamic corporate governance. The demand for governance is caused by the crisis in the banking sector which was dominated by conventional banking in 1997 which continued until 2000. Banking crisis that hit Indonesia is not as a result of the decline in the rupiah exchange rate, but due to the unfavorable practice of Good Corporate Governance among banks. The occurrence of violations of the maximum crediting limits, the low level of risk management practices, the lack of transparency of financial information to customers, and the dominance of shareholders in regulating banking operations led to the fragility of the national banking industry (Maradita, 2014).

Therefore, by applying good corporate governance especially have added value based on Islamic principles, give indication and impression to society that sharia institution especially bank avoid from practice of fraud, although cheating alone can happen anywhere.

Several previous studies that examined corporate governance in Islamic banks, such as those conducted by Maradita (2014) that compares the characteristics of governance in Islamic banks with conventional banks, in addition there is also research El Junusi (2012) who examines the implementation of sharia governance And its implications for the reputation and trust of sharia banks, which shows the result that the implementation of sharia governance affects the reputation and trust of customers. Then research conducted by Asrori (2014) which examines the implementation of Islamic corporate governance and its implications on the performance of Islamic banks, which shows the results of Islamic corporate governance affect the performance of Islamic banks. There is also research on the role of GCG in fraud prevention by Anugerah (2014), which shows the result that the implementation of internal and external mechanisms of Corporate Governance by observing and implementing all principles and functions can reduce the occurrence of fraud.

Based on research on Based on research on Islamic corporate governance and its influence on fraud as mentioned above it can be seen that the better implementation of corporate governance is expected to be less number of fraud that occurs in Islamic banks.

Whether or not the implementation of governance in Islamic banks can be seen from the results of self assessment conducted by Islamic banks in accordance with the procedures described in Circular Letter No. BI. 12/13 / DPbS on the implementation of GCG for Sharia Commercial Bank and Sharia Business Unit, where in the BI Circular is the assessment of the implementation of corporate governance in view of the composite value of self assessment results, which the smaller the composite value produced the better 
Level of implementation of governance in the Islamic bank. Then it can be concluded that the smaller the composite value of self assessment results of Islamic banks is expected to be fraud that occurs lower or decrease. So that can be prepared research hypothesis as follows:

H7 : Islamic Corporate Governance positively affects fraud in Islamic Bank.

Based on the Explanation in hypothesis 1 to hypothesis 7, it can be concluded that:

H8 : Islamic Income Ratio (IsIR) mediates Islamic Corporate Governance against fraud in Islamic Bank

H9 : Profit Sharing Ratio (PSR) mediates Islamic Corporate Governance against fraud in Islamic Bank

H10: Islamic Investment Ratio (IIR) mediates Islamic Corporate Governance against fraud in Islamic Bank

\section{METHOD}

Research design. This research is an explanatory research, with hypothetico-deductive approach that aims to obtain the clarity of phenomena that occur in the world empirically and trying to get answers (verification) with the aim to explain the influence between variables in order to test the hypothesis.

Population and Sample. The population in this study are all Sharia Commercial Banks (BUS) registered at Bank Indonesia in 2013 until 2016. The reason for choosing Bank as the population of cause, according to research conducted by ACFE (Association of Certified Fraud Examiner) (2012) bank become one Most industries are victims of fraud and consideration of the selection of Sharia Banks because Sharia Bank has its own principles in carrying out its activities. Sample selection method used in this research is purposive sampling method. The criteria are as follows:Samples are Sharia Commercial Banks (BUS) registered with Bank Indonesia respectively for the period 2013, 2014, 2015 and 2016 and Disclose data relating to research variables and available in full (overall data available in publications during the period 2013-2016)

Research Variable. Dependent variable in this research is fraud. Fraud in this study is measured by looking at the number of internal fraud occurring in Islamic banks disclosed in the annual report on the implementation of GCG of each sharia bank. The amount of internal fraud is used because in this study focuses on fraud that occurs in occupational relations (occupational fraud) or also called internal fraud. Furthermore, the mediation variable in this study is the Islamic financial performance index measured by using three proxies. First, the Islamic Income Ratio (ISIR) is measured by dividing Islamic Islamic bank revenue by total revenue. Second, Profit Sharing Ratio (PSR) is measured by dividing the amount of mudharabah and musyarakah financing with total Islamic bank financing. Third, Islamic Investment Ratio (IIR) is measured by dividing Islamic bank investment with total investment (Hameed et al, 2004). Independent variable used in this research is Islamic Corporate Governance which is measured by using composite value of GCG self-assessment of Islamic bank. 
Data Analysis Methods. This study uses path analysis. The model of regression equation used in this research is formulated as follows:
IsIR $=\mathrm{a}+\mathrm{b} 1 \mathrm{ICG}+\mathrm{e}$
(Equation 1)
PSR $=a+b 1$ ICG $+e$
(Equation 2)
$\mathrm{IIR}=\mathrm{a}+\mathrm{b} 1 \mathrm{ICG}+\mathrm{e}$
(Equation 3)
$\mathrm{Y}=\mathrm{a}+\mathrm{b} 1 \mathrm{ICG}+\mathrm{b} 2 \mathrm{IsIR}+\mathrm{b} 3 \mathrm{PSR}+\mathrm{b} 4 \mathrm{IIR}+\mathrm{e}$
(Equation 4)

where: Y : Fraud; a : Constants; b : Regression Coefficients; IsIR : Islamic Income Ratio; PSR : Profit Sharing Ratio; IIR : Islamic Investment Ratio; ICG : Islamic Corporate Governance

The Results of Statistical Tests. This study conducted several tests, namely the classical assumption test (normality test,multicolonierity, autogeneration, heteroscedasticity and linearity) (can be seen in appendix)and hypothesis test (test of determination coefficient, $F$ test and t test), then discussed abouthypothesis test result Presented in table 1.Substructure Analysis

Table 1. Hypothesis Test Results

\begin{tabular}{|c|l|l|l|}
\hline \multirow{4}{*}{ R Square } & Equation 1 & 0,029 \\
\cline { 2 - 4 } & Equation 2 & 0,014 \\
\cline { 2 - 4 } & Equation 3 & 0,004 \\
\cline { 2 - 4 } & Equation 4 & 0,410 \\
\hline \multirow{4}{*}{ F Test } & \multirow{2}{*}{ Equation 4 } & F & 7,311 \\
\cline { 2 - 4 } & & Sig & 0,000 \\
\hline \multirow{4}{*}{ t Test } & Equation 1 & Sig.ICG & 0,209 \\
\cline { 2 - 4 } & Equation 2 & Sig.ICG & 0,409 \\
\cline { 2 - 4 } & Equation 3 & Sig.ICG & 0,665 \\
\cline { 2 - 4 } & & Sig.ICG & 0,257 \\
\cline { 2 - 4 } & \multirow{2}{*}{ Equation 4 } & Sig.IsIR & 0,033 \\
\cline { 3 - 4 } & & Sig.PSR & 0,026 \\
\cline { 3 - 4 } & & Sig.IIR & 0,000 \\
\hline
\end{tabular}

Source: Data processed

Based on Table 1 the magnitude of the influence of Islamic Corporate Governance on Islamic Income Ratio is $2.9 \%$. The amount of influence of Islamic Corporate Governance on Profit Sharing Ratio is $1.4 \%$. The amount of influence of Islamic Corporate Governance on Islamic Investment Ratio is $0.4 \%$. The amount of influence of Islamic Corporate Governance, Islamic Income Ratio, Profit Sharing Ratio and Islamic Investment Ratio to Fraud in Sharia Bank is simultaneously $41 \%$.

$\mathrm{F}$ test results in table 1 in the F value can calculate 7.311 with Sig. 0,000 (Equation 4 ), since the probability value of significance is much smaller than 0.05 indicating that the regression model is feasible and correct.

The result of statistic test $\mathrm{t}$ in table 1 , for equation 1, Islamic Corporate Governance is not significant because it has significance value that is above 0,05 that is 0,209 . So it can be concluded that Islamic Corporate Governance has no effect on Islamic Income Ratio. 
Equation 2, Islamic Corporate Governance is not significant because it has a significance value that is above 0.05 is 0.409 . So it can be concluded that Islamic Corporate Governance does not affect the Profit Sharing Ratio.

Equation 3, Islamic Corporate Governance is not significant because it has a significance value that is above 0.05 is 0.665 . So it can be concluded that Islamic Corporate Governance has no effect on Islamic Investment Ratio.

Equation 4, Islamic Income Ratio, Profit Sharing Ratio and Islamic Investment Ratio (Islamicity Financial Performance Index) is significant because it has a significance value that is below $0,050.000,0,026$ and 0,000 . So it can be concluded from the four independent variables in the regression model in equation 4 there are three independent variables namely Islamic Income Ratio, Profit Sharing Ratio and Islamic Investment Ratio (Islamicity Financial Performance Index) which affects the dependent variable Fraud at Islamic Bank.

\section{Testing of Mediation Variables}

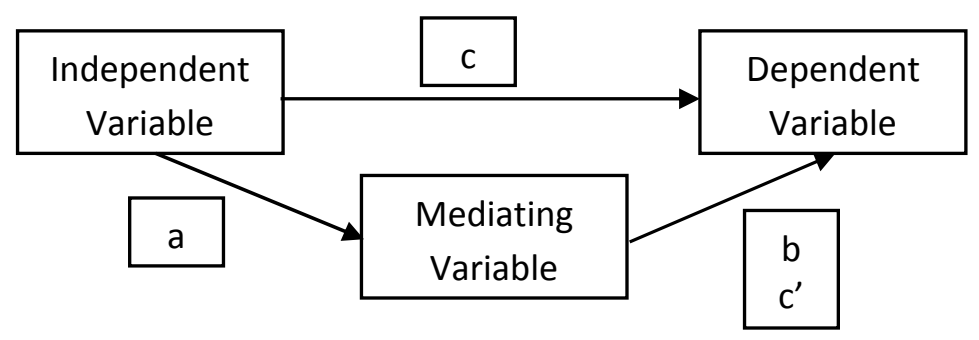

Figure 3. Causal Step Strategy

Significant coefficients $a$ and $b$ are sufficient to indicate the presence of mediation. If $\mathrm{c}$ is significant then there is partial mediation, but if $\mathrm{c}$ is not significant then there is full mediation (Preacher and Hayes, 2004).

Table 2.Test Result Causal Step

\begin{tabular}{lcccc}
\hline \multicolumn{1}{c}{ Variable } & a & b & c & C' \\
\hline Sig. ICG with IsIR-mediated & 0,3194 & 0,2926 & 0,3122 & 0,2543 \\
Sig. ICG with PSR-mediated & 0,4139 & 0,0000 & 0,2267 & 0,3608 \\
Sig. ICG with IIR-mediated & 0,9645 & 0,0000 & 0,0066 & 0,0017 \\
\hline
\end{tabular}

Source: Data processed

Based on Table 2 it can be concluded that the Islamic Income Ratio, Profit Sharing Ratio and Islamic Investment Ratio (Islamicity Financial Performance Index) does not mediate the influence of Islamic Corporate Governance on Fraud on Islamic Bank or it can be said that there is no mediation.

Discussion. The influence of Islamic Corporate Governance on the Islamicity Performance Index. The result of statistical test on this hypothesis shows that the variable of Islamic Corporate Governance has no effect on Islamic Income Ratio, Profit Sharing Ratio and Islamic Investment Ratio (Islamicity Financial Performance Index). 
Based on the existing theory, the implementation of corporate governance becomes very important in carrying out the operational activities of the company and in creating an effective and efficient business. However, in its implementation it is very difficult to apply maximal corporate governance especially for Islamic banks that use sharia or Islamic law as its principle, which is Islamic bank in Indonesia that is still new so that it is still in stage of adjustment and development so as not yet fully apply the principle Islam. Perhaps for that reason, Islamic corporate governance in Islamic banks at this time has not effectively influenced the Islamic Income Ratio, Profit Sharing Ratio and Islamic Investment Ratio (Islamicity Financial Performance Index), so it needs to be done continuously on the implementation of corporate governance To conform to Islamic principles as well as effective to apply.

Effect of Islamicity Financial Performance Index on Fraud. The result of statistic test on this hypothesis shows the variable of Islamic Income Ratio, Profit Sharing Ratio and Islamic Investment Ratio (Islamicity Financial Performance Index) affect to fraud, this is in accordance with the hypothesis. This supports previous research conducted by Najib (2016) which states that Profit Sharing Ratio effect on fraud, Rationalization is an important element in fraud triangle. Cendrowski et al (2007) rationalization is a form of justification by the perpetrators of fraud. Islamicity Financial Performance Index as an element of rationalization, is one of the things that prevent the occurrence of such fraud, can be interpreted that when the Islamicity Financial Performance Index is high then the number of fraud that occurs low, it means that the sharia bank is doing its activities in accordance with the principles of sharia or The high level of compliance of sharia banks, the lower the fraud that occurs in the bank. This indicates that Sharia principles when applied properly can reduce the rate of occurrence of fraud.

The Influence of Islamic Corporate Governance on Fraud. The result of statistical test on this hypothesis shows that Islamic Corporate Governance has no effect on fraud. The results of this study support the results of previous studies conducted by Najib (2016). The results of this study is different from the theory of fraud triangle which states that opportunities affect the fraud. Islamic Corporate Governance as an element of opportunity should be able to prevent fraud, but the Islamic Corporate Governance of the research sample has not been able to suppress the occurrence of fraud. This may result from fraud being caused by other factors outside the study. Fraud is an indicator in this fraud is internal fraud conducted by the management level downward (employee), which according to Silverstone (2007) fraud committed by the party generally occurs due to weak supervision such as internal audit, business complexity and weak rules in field.

The Role of Mediation of Islamicity Financial Performance Index. Based on the causal step test it can be concluded that the Islamic Income Ratio, Profit Sharing Ratio and Islamic Investment Ratio (Islamicity Financial Performance Index) does not mediate the influence of Islamic Corporate Governance on Fraud on Islamic Bank.

\section{ENDING}

Based on the results of the analysis, hypothesis testing, discussion and research that has been done then can put forward some conclusion research as follows: 1) Islamic Corporate 
Governance has no effect on to Islamicity Performance Index, 2) Islamic Income Ratio, Profit Sharing Ratio and Islamic Investment Ratio Financial Performance Index) influences Fraud, 3) Islamic Corporate Governance has no effect on Fraud, and 4) Islamic Income Ratio, Profit Sharing Ratio and Islamic Investment Ratio (Islamicity Financial Performance Index) does not mediate the influence of Islamic Corporate Governance on Fraud in Islamic Bank.

The implications of this research for the banks is to pay more attention disclosure of corporate governance and further strengthen its internal controls to reduce fraud.As for the financial services authority is issuing the rules relating to corporate governance disclosure level rise.

The limitations of this study should be considered for future research are: (1) The need to expand the population by adding other types of Islamic financial institutions such as Syariah Business Unit, Islamic Rural Bank or Sharia Insurance.; (2) Using different proxies to measure variables of Islamic Corporate Governance and Islamic Financial Financial Performance Index; (3) Adding other variables that might have an impact on fraud in Islamic banks.

\section{REFERENCES}

Albrecht, W. S., Albrecht, C. O., Albrecht, C. C., \&Zimbelman, M. F. (2011). Fraud examination. Cengage Learning.

Algaoud, L. M., \& Lewis, M. K. (2001). Perbankan Syariah; Prinsip, Praktik, danProspek. Jakarta: Serambi.

Anugerah, R. (2014). Peranan Good Corporate Governance dalam Pencegahan Fraud. Jurnal Akuntansi, 3(1), 101-113.

Asrori. (2011). Pengungkapan Syariah Compliance dan Kepatuhan Bank Syariah Terhadap Prinsip Syariah, Jurnal Dinamika Akuntansi, 3 (1).

Asrori. (2014). Implementasi Islamic Corporate Governance dan Implikasinya Terhadap Kinerja Bank Syariah, Jurnal Dinamika Akuntansi, 6 (1).

Association of Certified Fraud Examiners (ACFE). (2009), Report to the Nation on Occupational Fraud and Abuse, 2012. Bank Indonesia.Peraturan Bank Indonesia No 11/33/PBI/2009 tentangPelaksanaan Good Corporate Governance bagi Bank UmumSyariahdan Unit Usaha Syariah.Lembar Negara RI Tahun 2009, No.175 DPbS. MenteriHukumdan HAM. Jakarta.

Bank Indonesia (2010). Peraturan Bank Indonesia No 13/2/PBI/2011 tentang Pelaksanaan Fungsi Kepatuhan Bank Umum. Lembar Negara RI Tahun 2011, No. 6 DPNP. Menteri Hukum dan HAM. Jakarta. 2011. Bank Indonesia. Surat Edaran Bank Indonesia Nomor 12/13/DPbSTahun 2010 TentangPelaksanaan Good Corporate Governance bagi Bank UmumSyariahdan Unit Usaha Syariah.Jakarta.

Bank Indonesia (2011).Surat Edaran Bank Indonesia Nomor 13/28/DPNP Tahun 2011 Tentang Penerapan Strategi Anti Fraud bagi Bank Umum. Jakarta.

Besari, B. (2009). Pengaruh Kualitas Pelaksanaan Good Corporate Governance, Ukuran (Size) Dan Kompleksitas Bank Terhadap Fraud (KasusPada Bank UmumTahun 2007) (Doctoral dissertation, Diponegoro University).

Cressey, D. (1953). Other people's money, dalam:"Detecting and Predicting Financial Statement Fraud: The Effectiveness of The Fraud Triangle and SAS No. 99, 
Skousen et al. 2009. Journal of Corporate Governance and Firm Performance, 13, 53-81.

Djumena, Erlangga (2016). Bank Mega Syariah Terseret Kasus Investasi Emas?.http://bisniskeuangan.kompas.com/read/2014/05/08/0821423/Bank.Mega.Sy ariah.Terseret.Kasus.Investasi.Emas.

El Junusi, R. (2012). Implementasi Shariah Governance serta Implikasinya terhadap Reputasi dan Kepercayaan Bank Syariah.Al-Tahrir: Jurnal Pemikiran Islam, 12(1), 87-111.

Falikhatun danYasmin Umar Assegaf (2012).Bank Syariah di Indonesia: Ketaatan Pada Prinsip-Prinsip Syariah dan Kesehatan Finansial, CBAM-FE UNISSULA, Volume 2 Nomor 1.

Faozan, A. (2014). Implementasi good corporate governance dan peran dewan pengawas syariah di bank syariah. La_Riba, 7(1), 1-14.

Febianto, Irawan (2011). Analisis Laporan Tahunan Dewan Pengawas Syariah (DPS) Pada Bank Syariah di Indonesia, Universitas Padjadjaran, 2011.

Forum for Corporate Governance in Indonesia. (2001). Peranan Dewan Komisaris dan Komite Audit dalam Pelaksanaan Corporate Governance (Tata Kelola) (3rd ed.). Jakarta: Forum for Corporate Governance in Indonesia.

Ghozali, Imam (2006). AplikasiAnalisis Multivariate dengan Program SPSS, Semarang: BadanPenerbitanUniversitasDiponegoro.

Hameed, Shalul. et al. (2004). Alternative Disclosure and Performance Measures for Islamic Banks, International Islamic University Malaysia,

Hermawan, Ancella Anitawati dan Miranti Martin. (2013). Pengaruh Kebijakan Dividen terhadap Potensi Pertumbuhan Laba Perusahaan Keluarga, Simposium Nasional Akuntansi XVI, Manado.

In'airat, M. (2015). The Role of Corporate Governance in Fraud Reduction-A Perception Study in the Saudi Arabia Business Environment.Journal of Accounting \& Finance, 15(2)., (2158-3625)

Jensen, M. C., and W. Meckling. (1976).Theory of the Firm: Managerial Behavior, Agency Costs, and Ownership Structure, Journal of Financial Economic 3, 305-360.

Jumansyah, \& Syafei, A. W. (2013). Analisis Pengaruh Good Governance Business Syariah dan Penerapan Maqasid Shariah Bank Syariah di Indonesia. Jurnal Al Azhar Indonesia Seri Pranata Sosial.

Komite Nasional Kebijakan Governance. (2012). Prinsip Dasar dan Pedoman Pelaksanaan Good Corporate Governance Perbankan Indonesia.

ModulInvestigasi. (2008). Memahami Fraud dan Melaksankan Investigative Audit pada Perusahaan/Korporasi. Jakarta:LembagaPengembangan Fraud Auditing (LPFA), 2008

Maradita, A. (2014). Karakteristik Good Corporate Governance Pada Bank Syariahdan Bank Konvensional.Yuridika, 29(2).

Meilani, S. E. (2015). Hubungan Penerapan Good Governance Business Syariah Terhadap Islamicity Financial Performance Index Bank Syariah di Indonesia. Seminar Nasional dan The 2nd Call for Syariah Paper.

Natalia, Debby. (2013). Pengaruh Mekanisme Good Corporate Governance terhadap Praktik Earning Management Badan Usaha Sektor Perbankan di BEI 2008-20011. Jurnal Ilmiah Mahasiswa Universitas Surabaya, 2 (1)

Otoritas Jasa Keuangan (2015). Statistik Perbankan Syariah. 
Ponduri, S. B., Sailaja, V., \& Begum, S. A. (2014). Corporate Governance-Emerging economies fraud and fraud prevention.IOSR, Journal of Business and Management, 16(3), 1-7.

Prabowo, Dani. (2016). Kredit Fiktif BSM Terendus Sejak 2012, 3 Pegawai Sudah Dipecat.http://megapolitan.kompas.com/read/2013/10/24/2349078/Kredit.Fiktif.BS M Terendus.sejak. 2013. Pegawai Sudah Dipecat

Putri, AlvyraNesia Indah dan Indira Januarti. (2014). Faktor-Faktor yang Berpengaruh Terhadap Audit Report Lag Pada Perusahaan Manufaktur yang Terdaftar Di Bursa Efek Indonesia periodetahun 2008-2012, Diponegoro Journal Of Accounting, 3 (2) $1-10$.

Rahman, R. A., \& Anwar, I. S. K. (2014). Effectiveness of fraud prevention and detection techniques in Malaysian Islamic banks. Procedia-Social and Behavioral Sciences, 145, 97-102.

Rahmawati, H. I. (2013). Pengaruh good corporate governance (GCG) terhadap manajemen laba pada perusahaan perbankan. Accounting Analysis Journal, 2 (1), 918.

Republik Indonesia (1998). Undang-Undang Nomor 10 Tahun 1998 tentang Perubahan Atas Undang-Undang Nomor 7 Tahun 1992 tentang Perbankan. Lembar Negara RI Tahun 1998, No. 182. Menteri Negara Sekertaris Negara. Jakarta.

Republik Indonesia. (2008). Undang-Undang Nomor 21 Tahun 2008 tentang Perbankan Syariah. Lembar Negara RI Tahun 2008, No. 94. Sekertariat Negara. Jakarta.

Rini, R. (2014). "The effect of audit committee role and sharia supervisory board role on financial reporting quality at Islamic banks in Indonesia". Journal of Economics, Business \& Accountancy Ventura, 17(1), 145-156.

Rodoni, A. dan Hamid, A. (2007). Lembaga Keuangan Zikrul Hakim, Jakarta, Indonesia.

Sebtianita, E. (2015). Analisis Kinerja Bank Umum Syariah Dengan Menggunakan Pendekatan Islamicity Performance Index (Studi Pada Bank Umum Syariah periode tahun 2009-2013). Jurnal Fakultas Ekonomi UIN Malang, hal. 3.

Sudaryati, D \& Eskadewi, Y. (2012). Pengaruh Corporate Governance Terhadap Tingkat Pengungkapan Corporate Social Responsibility di Bank Syariah. Jurnal Ekonomi dan Bisnis, 11 (1), 14-28

Sukardi, B. (2012). Kepatuhan Syariah (Shariah Compliance) Dan Inovasi Produk Bank Syariah Di Indonesia. AKADEMIKA: JurnalPemikiran Islam, 17(2), 235-252.

Sukardi, B. (2013). Corporate Governance Engineering of Islamic Banking and Finance: Tantangan Globalisasi Sistem Ekonomi dan Pasar Bebas. Tsaqafah, 9(1), 149-170.

Sula, A. E., \&Alim, M. N. (2014).Pengawasan, strategiantifraud, dan audit kepatuhan syariah sebagai upaya fraud preventive pada lembaga keuangan syariah. Journal of Auditing, Finance, and Forensic Accounting, 2(2), 91-100.

Thanasak, Ruankew. (2013). The Fraud Factors. International Jurnal of Management and Administrative Sciences (IJMAS). 2 (2), 1-2.

The Institute of Internal Auditors. (2012). International Standards for the Professional Practice of Internal Auditing (Standards).

Tiscini, R., \& Di Donato, F. (2006). The relation between accounting frauds and corporate governance systems: an analysis of recent scandals.

Triyanta, A. (2009). Implementasi Kepatuhan Syariah dalam Perbankan Islam (Syariah) (Studi Perbandingan antara Malaysia dan Indonesia). Jurnal Hukum Ius QuiaIustum, 16 . 
Tuanakotta, Theodorus M. (2012). Akuntansi Forensik dan Audit Investigatis Edisi 2. Jakarta: Salemba Empat,

Undang-Undang No.10 Tahun 1998 tentangPerbankan.

Undang-Undang No.21 Tahun 2008 tentangPerbankanSyariah.

Wijaya, Angga Sukma. (2016). Kasus Gadai Emas Perburuk Citra Produk Syariah.https://m.tempo.co/read/news/2012/10/04/087433724/kasus-gadai-emasperburuk-citra-produk-syariah.

Yaya, R., Martawireja, A. E., \&Abdurahim, A. (2014). Akuntansi Perbankan Syariah: Teori dan Praktik Kontemporer berdasarkan PAPSI 2013 edisi 2. Salemba Empat. www.bi.go.id 